Parker, P. G., A. A. Snow, M. D. Schug, G. C. BooTON, AND P. A. FUERST. 1998. What molecules can tell us about populations: choosing and using a molecular marker. Ecology 79:361-382.

Paulus, K. B., And R. Tiedemann. 2003. Ten polymorphic autosomal microsatellite loci for the Eider Duck Somateria mollissima and their crossspecies applicability among waterfowl species (Anatidae). Molecular Ecology Notes 3:250-252.

RAYMOND, M., AND F. ROUSSET. 1995. GENEPOP (v.1.2). A population genetics software for exact tests and ecumenicism. Journal of Heredity 86: $248-249$.

Reilly, A., N. G. Elliott, P. M. Grewe, C. Clabby, R. Powell, AND R. D. WARD. 1999. Genetic differentiation between Tasmanian cultured atlantic salmon (Salmo salar L.) and their ancestral Canadian population: comparison of microsatellite DNA and allozyme and mitochondrial DNA variation. Aquaculture 173:459-469.

Rhodes, O. E., JR, L. M. Smith, AND M. H. SMith. 1991. Conservation and genetic resources in waterfowl, p. 462-472. In Transactions of the $56^{\text {th }}$ North American Wildlife and Natural Resources Conference. Wildlife Management Institute, Edmonton, Alberta, Canada.

RICE, W. R. 1989. Analyzing tables of statistical tests. Evolution 43:223-225.

Ross, K. G., D. D. Shoemaker, M. J. B. Kreiger, C. J. DeHeer, and L. Keller. 1999. Assessing genetic structure with multiple classes of molecular markers: a case study involving the introduced fire ant Solenopsis invicta. Molecular Biology and Evolution 16:525-543.

Sambrook, J., E. F. Fritsch, and T. Maniatis. 1989. Molecular cloning: A laboratory manual. 2nd ed. Cold Spring Harbor Laboratory Press, Woodbury, NY.

Sauer, J. R., J. E. Hines, I. Thomas, J. Fallon, And G. Gough. 2000. The North American Breeding Bird Survey, results and analysis 1966-1999. Version 98.1. USGS Patuxent Wildlife Research Center, Laurel, MD.

Scribner, K. T., P. A. Crane, W. J. Spearman, and L. W. SEEB. 1998. DNA and allozyme markers provide concordant estimates of population differentiation: analyses of US and Canadian populations of Yukon River fall-run chum salmon (Oncorhynchus keta). Canadian Journal of Fisheries and Aquatic Sciences 55:1748-1758.

Shaw, P. W., G. J. Pierce, and P. R. Boyle. 1999. Subtle population structuring within a highly vagile marine invertebrate, the veined squid Loligo forbesi, demonstrated using microsatellite DNA markers. Molecular Ecology 8:407-417.

StutzenbaKer, C. D. 1988. The Mottled Duck, its life history, ecology and management. Texas Parks and Wildlife Department, Austin, TX.

Taylor, M. F. J., Y. Shen, and M. E. Kreitman. 1995. A population genetic test of selection at the molecular level. Science 270:1497-1499.

Williams, C. L., R. C. Brust, and O. E. Rhodes JR. 2002. Microsatellite polymorphism and genetic structure of Florida Mottled Duck populations. Condor 104:424-431.

\title{
PARENTAL BODY CONDITION DOES NOT CORRELATE WITH OFFSPRING SEX RATIO IN CORY'S SHEARWATERS
}

\author{
M. Genovart ${ }^{1,3}$, D. Oro ${ }^{1}$, M. G. Forero ${ }^{1}$, J. M. Igual ${ }^{1}$, J. GonzÁlez-Solís ${ }^{2}$ And X. Ruiz ${ }^{2}$ \\ ${ }^{1}$ Institut Mediterrani d'Estudis Avançats IMEDEA (CSIC-UIB), Miquel Marquès 21, 07190 Esporles, \\ Mallorca, Spain \\ ${ }^{2}$ Dept. Biologia Animal, Vertebrats, Universitat de Barcelona, Avgda. Diagonal 645, 08028 Barcelona, Spain
}

Abstract. We analyzed offspring sex ratio variation in Mediterranean Cory's Shearwater (Calonectris $d$. diomedea) during two consecutive breeding seasons in two colonies. We test for differential breeding conditions between years and colonies looking at several breeding parameters and parental condition. We then

Manuscript received 20 February 2004; accepted 3 November 2004.

${ }^{3}$ E-mail: m.genovart@uib.es explored the relationship between offspring sex ratio and parental condition and breeding parameters. This species is sexually dimorphic with males larger and heavier than females; consequently we expected differential parental cost in rearing sexes, or a greater sensitivity of male chicks to adverse conditions, which may lead to biased sex ratios. Chicks were sexed molecularly by the amplification of the CHD genes. Offspring sex ratio did not differ from parity, either at hatching or fledging, regardless of the colony or year. However, parental body condition and breeding param- 
eters such as egg size and breeding success were different between years and colonies. Nevertheless, neither nestling mortality nor body condition at fledging varied between years or colonies, suggesting that male and female chicks were probably not differentially affected by variability in breeding conditions.

Key words: body condition, Calonectris diomedea, Cory's Shearwater, egg volume, sex ratio.

\section{La Condición Parental no está Correlacionada} con las Proporciones de Sexos en los Pollos de Calonectris $d$. diomedea

Resumen. Se analizaron las proporciones de sexos en la descendencia en dos colonias mediterráneas de Calonectris $d$. diomedea, durante dos temporadas de cría consecutivas. Se estudió la relación entre la proporción de sexos de los pollos y la condición parental y algunos parámetros reproductivos durante la cría. La especie es dimórfica, siendo los machos mayores y más pesados que las hembras; en consecuencia, se esperarían costos parentales diferenciales en la cría de los sexos, o una sensibilidad mayor de los pollos machos a condiciones adversas, que se traduciría en un sesgo en la proporción de sexos. Se determinó el sexo de los pollos por medio de técnicas moleculares, mediante la amplificación del gen CHD. Las proporciones de sexos en los pollos no se desviaron del $50 \%$ ni en la eclosión, ni en los volantones, independientemente de la colonia o el año de estudio. Sin embargo, la condición parental y algunos parámetros reproductivos como el tamaño del huevo o el éxito reproductivo sí variaron entre años y colonias. La mortalidad o la condición física de los volantones tampoco mostraron ninguna variación en función de la colonia o del año de estudio, sugiriendo que los pollos de los dos sexos probablemente no se vieron afectados de manera diferencial por la variabilidad en las condiciones de cría.

Fisher's (1930) theory of equal investment in male and female offspring leads to predictions for sex ratios similar to those that arise from a model of random segregation of sex chromosomes at meiosis. In both cases, without sex differential rearing costs, we would expect parity in offspring sex ratios. However, in species that are sexually dimorphic, a differential cost in rearing males and females (due to higher parental investment for raising offspring of the larger sex, or to a greater mortality of the larger sex during rearing) could lead to biased offspring sex ratios at the population level (Charnov 1982). At an individual level, if sexes differ in fitness and these differences depend on conditions at the time of breeding, natural selection would favor facultative adjustment of offspring sex ratios (Trivers and Willard 1973, Charnov 1982). Several avian studies have reported biases in primary and secondary sex ratios at hatching and at fledging (Clutton-Brock 1986, Dijkstra et al. 1990, Arroyo 2002, Van den Burg et al. 2002); some due to differential hatching success or chick mortality (Olsen and Cockburn 1991, Torres and Drumond 1997, Nager et al. 2000), and others to parental manipulation of primary sex ratios (Ellegren et al. 1996, Komdeur et al. 1997, Korpimäki et al. 2000, Whittingham and Dunn 2000).
Some breeding parameters such as egg size and breeding success can reflect environmental or parental conditions at the time of breeding (Croxall et al. 1992, Weidinger 1996, Mougin 1998). Thus, reduced food intake due to lower parental foraging efficiency or a decreased availability of resources, would be reflected in these breeding parameters and comparisons between colonies and years may provide valuable information on breeding conditions. The relationships between parental condition, breeding parameters, and secondary sex ratio have scarcely been explored in Procellariiformes and studies are usually restricted to one colony or breeding season (but see Bretagnolle and Thibault 1995, Weimerskirch et al. 2000).

The Mediterranean Cory's Shearwater (Calonectris d. diomedea) is a sexually dimorphic seabird with males about $10 \%$ larger than females (Thibault et al. 1997). Females lay a single-egg clutch and chicks show slow development (Thibault et al. 1997). If sex ratio manipulation occurs, birds laying a single-egg clutch may have the ability to adjust offspring sex ratio by absorbing a zygote of the inappropriate sex without incurring the costs of a significant extension of time to clutch completion or by increasing population hatching asynchrony (Emlen 1997) and consequently, we may expect stronger deviations from equity within the population. However, egg formation in Procellariiformes is costly; it takes a long time, replacement clutches are rare, and only a single follicle may undergo rapid yolk deposition during a breeding season (Astheimer and Grau 1990).

Sexual size dimorphism could lead to greater food requirements of the larger sex and may result in a greater sensitivity to resource limitation during the nestling stage (Torres and Drummond 1997, 1999, Weimerskirch et al. 2000). However in many Procellariiformes, rates of chick mortality during the nestling stage are low and consequently primary and secondary sex ratio would be similar. Mortality may increase during migration to the wintering grounds, when juveniles have to forage by themselves. In fact, body condition at fledging has been shown to affect later survival in several species (Hochachka and Smith 1991, Magrath 1991, Mougin et al. 2000) thus differential mortality or fitness gains between sexes could be assessed by differential fledging condition. Differences in mortality or fledging condition between male and female offspring would imply differential costs between sexes. This asymmetry would favor facultative manipulation of offspring sex ratios, whereas equality in survival and fledging condition between sexes would not justify the evolution of parental manipulation of sex ratio.

Our objectives were to assess population level offspring sex ratio in Cory's Shearwater in two different colonies (Pantaleu and Congreso) and years (2001 and 2002). We explored variation in parental condition and breeding parameters in both colonies and years to determine whether parental condition was correlated among breeding parameters and with offspring sex ratio. Finally, we tested whether fledging condition depended on offspring sex or colony or year.

\section{METHODS}

Data were collected during 2001 and 2002 in two Mediterranean colonies, Pantaleu and Congreso Is- 
lands. Pantaleu is a small, protected island in the Balearic Archipelago $200 \mathrm{~m}$ off the S-W coast of Mallorca $\left(39^{\circ} 34^{\prime} \mathrm{N}, 2^{\circ} 20^{\prime} \mathrm{E}\right)$, where approximately 200 pairs of Cory's Shearwater bred during the years of this study (Genovart 2001). The Congreso colony is located at the Chafarinas Archipelago, $4.5 \mathrm{~km}$ off the Moroccan Mediterranean coast $\left(35^{\circ} 11^{\prime} \mathrm{N}, 3^{\circ} 46^{\prime} \mathrm{E}\right)$ and supports a minimum of 800 breeding pairs (Igual and Gómez 2000). The distance between the two colonies is about $600 \mathrm{~km}$.

Egg volume and breeding success (as proportion of chicks that fledge from all nests with an egg laid) were recorded at both colonies. All nests found in Pantaleu and a random sample of nests in Congreso, were marked and when possible, eggs measured before hatching (maximum length and width $\pm 0.1 \mathrm{~mm}$ ) with digital calipers (for sample sizes see table 2). We calculated egg volume $\left(\right.$ in $\mathrm{cm}^{3}$ ) as $\mathrm{V}=0.00051 \times \mathrm{egg}$ length $\times$ egg width ${ }^{2}$ (Hoyt 1979, Sánchez and Castilla 1997).

After measuring eggs, nests were not disturbed until hatching. We determined hatching sex ratio in both colonies in 2001, and only at Pantaleu in 2002, and fledging sex ratio in both years and colonies. The hatching sex ratio was calculated from chicks sampled within three days of hatching. Fledging sex ratio was assessed from surviving chicks sampled at hatching, and from other chicks sampled few days before fledging. A small blood sample (ca. $50 \mu \mathrm{L}$ ) was taken from the femur vein of the chick, collected in a capillary tube and transferred to a tube with ethanol. We determined the sex of chicks using polymerase chain reaction (PCR) amplification of the CHD genes (Ellegren 1996, Griffiths et al. 1998). Blood was boiled in $100 \mathrm{mM} \mathrm{NaOH}$ for 10 minutes at $100^{\circ} \mathrm{C}$ before being added to the PCR reaction. PCR protocols were modified from Fridolfsson and Ellegren (1999) using the primer set $2550 \mathrm{~F}-2718 \mathrm{R}$, and products were run out on a $3 \%$ agarose gel stained with ethidium bromide. Gels were scored as males having a single band and females having two bands.

Body measurements of adults and chicks were taken in both years at Congreso, and only in 2002 at Pantaleu. Adults were weighed (always during incubation), and we took morphological measurements of wing length, bill depth at nostril, head and bill length, tarsus length and length of the third flight feather (P3). Chicks were weighed at fledging and wing length, bill depth, and head plus bill length were measured.

\section{STATISTICAL ANALYSIS}

Sex ratio deviations from parity were assessed using a binomial test (Zar 1996, Cockburn et al. 2002).

To determine if male and female chicks were differentially affected by breeding conditions, we assessed body condition of chicks at fledging in both colonies. As we lacked measures from Pantaleu in 2001, we performed two separate analyses. First, we tested for differences in chick body condition between years (2001 and 2002) at Congreso using a General Linear Model (GLM) with weight as the response variable, sex and year as factors, and bill depth, head plus bill length as covariates to correct for size, and wing length accounting for chick age. Wing length has been previously used as an estimator of chick age in this
TABLE 1. Population sex ratio (percent males) in Cory's Shearwater breeding in 2001 and 2002 at Pantaleu (Balearic Islands) and Congreso (Chafarinas Islands). Results of a binomial test investigating whether sex ratio differs from equality are shown.

\begin{tabular}{cccccccrc}
\hline \hline & \multicolumn{3}{c}{ Congreso } & & \multicolumn{3}{c}{ Pantaleu } \\
\cline { 2 - 3 } \cline { 7 - 8 } & $\begin{array}{c}\text { Sex } \\
\text { ratio }\end{array}$ & $n$ & $P$ & & $\begin{array}{c}\text { Sex } \\
\text { ratio }\end{array}$ & $n$ & $P$ \\
\hline Hatching & & & & & & & \\
2001 & 58 & 55 & 0.3 & & 50 & 120 & 1.0 \\
2002 & - & - & - & & 54 & 33 & 0.7 \\
Fledging & & & & & & \\
2001 & 57 & 63 & 0.3 & & 48 & 102 & 0.8 \\
2002 & 49 & 106 & 0.9 & & 49 & 79 & 1.0 \\
\hline
\end{tabular}

species (Granadeiro 1991, Hamer and Hill 1994), because it show less variance in growth rates and in other closely related species is unaffected by environmental factors such as food supply (Harris 1966, Ricklefs 1992); our findings also shown that wing length was highly correlated with age $(R=0.7 ; P<0.001)$. Second, we analyzed chick body condition in 2002 at both colonies. Following the same procedure, we used data from 2002 from both colonies to determine if chick body condition differed between colonies (GLM with weight as the response variable, sex and colony as factors, and bill depth and head plus bill length and wing length as covariates).

To determine if adult body condition differed between years we used a GLM with adult weight as the response variable, and sex and year as factors, and included an index of body size as a covariate. To calculate a body size index, we used a Principal Component Analysis (PCA) of body morphometrics (head plus bill length, bill depth, tarsus length, wing length and P3) from both years at Congreso, and we used the first principal component as an indicator of adult body size. To determine if adult body condition differed between colonies we computed a GLM of data from both colonies in 2002, with weight as the response variable, sex and colony as factors, and body size index (from a PCA of morphological characters for adults in both colonies in 2002).

All analyses were computed with SPSS (version 11.0). Data are presented as mean \pm SE and the level of significance was set at $P \leq 0.05$.

\section{RESULTS}

We did not find any bias in hatching or fledging sex ratios in either year or in either colony (Table 1). Breeding parameters recorded in both years and colonies are shown in Table 2. Eggs from Pantaleu were significantly smaller than at Congreso (Two way ANOVA; colony, $F_{1,374}=7.7, P<0.01$; year, $F_{1,374}=$ $0.1, P=0.7$; interaction year $*$ colony: $F_{1,374}=1.4$, $P=0.3$ ). Breeding success was significantly different between colonies only in $2001\left(2001, \chi^{2}{ }_{1}=5.7, P=\right.$ $0.02 ; 2002, \chi^{2}{ }_{1}=2.3, P=0.2$ ). Differences between years were also found in breeding success in Congreso 
TABLE 2. Egg volume (mean $\pm \mathrm{SE}$ ) and breeding success (percentage of chicks that fledged from all eggs laid) of Cory's Shearwaters breeding in Pantaleu and Congreso colonies in 2001 and 2002. Egg volume resulted significantly different in Pantaleu $(P<0.01)$.

\begin{tabular}{lccccc}
\hline \hline Colony & Year & \multicolumn{1}{c}{$n$} & $\begin{array}{c}\text { Egg volume } \\
(\mathrm{mL})\end{array}$ & $n$ & $\begin{array}{c}\text { Breed- } \\
\text { ing suc- } \\
\text { cess }\end{array}$ \\
\hline Congreso & 2001 & 60 & $75.6 \pm 9.7$ & 210 & $51 \%$ \\
& 2002 & 69 & $76.3 \pm 14.5$ & 220 & $71 \%$ \\
Pantaleu & 2001 & 136 & $74.3 \pm 4.9$ & 168 & $64 \%$ \\
& 2002 & 109 & $73.1 \pm 5.4$ & 139 & $63 \%$ \\
\hline
\end{tabular}

$\left(\chi^{2}{ }_{1}=25, P<0.001\right)$, but not in Pantaleu $\left(\chi^{2}{ }_{1}=0.04\right.$, $P=0.9$; Table 2). However, breeding success results should be taken with caution; at Congreso, predation by rats was the main cause of the breeding failure in 2001 whereas in Pantaleu predation by rats has not been detected (JMI, pers. obs.).

At Pantaleu chick mortality in 2001 did not differ between sexes, although chick mortality in this species is low and sample sizes were small.

Body condition at fledging did not differ between sexes, colonies, or years (Fig. 1). In 2002 body condition at fledging did not depend on the colony $\left(F_{1,183}\right.$ $=0.3, P=0.6)$, sex $\left(F_{1.183}=2.1, P=0.1\right)$ or their interaction $\left(F_{1,183}=0.2, P=0.7\right)$. In Congreso, chick fledging condition was also not affected by year $\left(F_{1,156}\right.$ $=0.6, P=0.4)$, sex $\left(F_{1,156}=2.3, P=0.1\right)$ or their interaction $\left(F_{1,156}=0.01, P=0.9\right)$.

Adult body condition in 2002 was significantly higher at Congreso than at Pantaleu $\left(F_{1,129}=25.4, P\right.$ $<0.001$; Fig. 2a) and did not differ between males and females (sex: $F_{1,129}=0.04, P=0.9$; interaction sex $*$ colony: $\left.F_{1,129}=2.8, P=0.1\right)$. When we analyzed adult body condition in both years at Congreso, we detected a significant year effect $\left(F_{1,171}=13.2, P<\right.$ 0.001 ), where adults in 2002 were in better condition than those in 2001 (Fig. 2b). There was no effect of sex or its interaction with year $\left(F_{1,171}=0.8, P=0.4\right.$; $F_{1,171}=0.31, P=0.6$ respectively; Fig. $\left.2 \mathrm{~b}\right)$.

\section{DISCUSSION}

Neither primary nor secondary population sex ratio differed from parity in Cory's Shearwater. These results were not correlated with any differences in parental condition or breeding parameters between years and colonies that reflect different breeding conditions. Variation in breeding conditions between colonies was minor in 2001, but conditions during breeding were apparently better at Congreso than at Pantaleu in 2002. Annual variation in breeding parameters at Congreso suggests that birds were in better condition in 2002 . This idea is reinforced by results in parallel work carried out with this species using nitrogen stable isotopes that indicates that individuals fed in significantly higher trophic levels in 2002 (MGF, unpubl. data).

The absence of a relationship between offspring sex ratio and variation in parental condition and breeding parameters supports a model of equal costs between sexes or a model of random segregation of sex chromosomes at meiosis. The absence of biased offspring sex ratio is common among Procellariiformes (Hunter 1984, Weimerskirch et al. 2000). However Bretagnolle and Thibault (1995) found biased sex ratio at fledging for chicks of Cory's Shearwater, but they combined data from several years and sexing of birds (using a discriminant function analysis), may not be completely accurate, thus results should be taken with caution. Other seabirds showed biases in primary sex ratio in natural (Meathrel and Ryder 1987, Torres and Drummond 1999, Szczys et al. 2001, Velando et al. 2002, Genovart et al. 2003), and experimental conditions
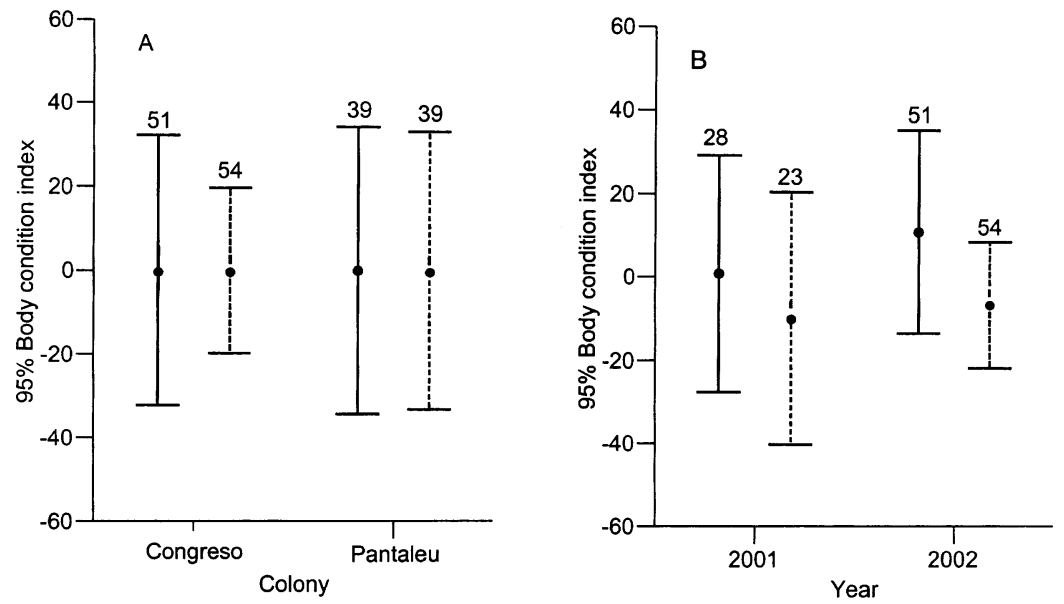

FIGURE 1. Comparison of male and female fledgling body condition (solid and dashed lines, respectively) between (A) colonies in 2002 and (B) years in Congreso. Body condition index was assessed as the residual value obtained from a GLM model with weight as dependent variable and the covariables of head length and bill depth to correct for body size, and wing length to correct for age. 

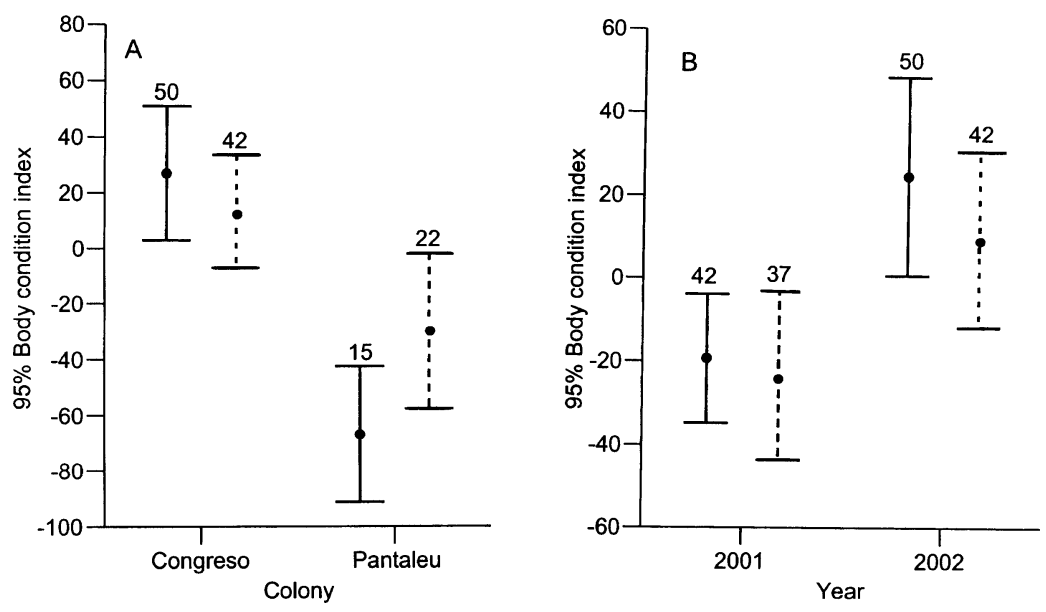

FIGURE 2. Comparison of male and female body condition (solid and dashed lines, respectively) between (A) colonies in 2002 and (B) years in Congreso. Body condition index was assessed as the residual value obtained from a GLM model with weight as a dependent variable, and a factor obtained from a CPA of several body measures, as a covariable to correct for body size.

(Nager et al. 1999), suggesting that constraints for sex ratio manipulation in Procellariiformes could be stronger than in other groups of seabirds. These constraints could be linked to adaptations of breeding in an unpredictable environment, such as single egg clutches and a prolonged nestling period (Boersma et al. 1980, Ricklefs et al. 1985, Boersma and Parrish 1998, Astheimer and Grau 1990).

Despite the sexual size dimorphism we did not find differences in chick fledging condition between sexes or colonies or years. The rate at which shearwater parents supply food under natural conditions may be close to the maximum assimilatory capacity of the chick's digestive tract (Hamer and Hill 1994). Under most environmental conditions, parents probably put all their effort into rearing a chick in good fledging condition, irrespective of the sex of the chick, even at the cost of decreasing their own body condition. However, in strongly depleted food conditions, adults may not be able to compensate and chicks could also be in poor body condition (Granadeiro et al. 1998). It is also expected that an increased breeding effort, due for example to a lower food availability, would not only reduce adult body condition during breeding but it could also constrain adults to breed next season (Calow 1979, Sibly and Calow 1989, Mínguez 1998).

Our limited data do not allow us to be conclusive, and more studies including several years and colonies should be carried out to confirm our hypothesis. However, we suggest that, although Procellariiformes can be highly sensitive to changes in food availability during breeding (Schreiber and Schreiber 1989, Ainley and Boekelheide 1990), differential sensitivity between sexes would be only detected under strongly depleted food conditions at breeding. Moreover the possible fitness benefits of manipulating offspring sex would not overcome the costs associated with biasing sex ratios in this species.
We are very grateful to all the people involved in fieldwork at both Islands over the years, especially to I. Afán, J. M. Arcos, P. Dietrich, G. García, J. Diez, T. Gómez, R. F. Graña, Josito, M. Louzao, G. Martínez, M. McMinn, I. Mola, M. Domínguez, A. Sastre, P. Sunyer, R. Pradel, and T. Roberts. We would like to thank Andy Green, Lluís Jover and Giacomo Tavechia for their statistical advice. Comments by two anonymous referees and David S. Dobkin greatly improved the manuscript. We would also like to thank the Parc Natural de Sa Dragonera and their wardens for their support and to Damià, from "El Pescador" for his help. We are also grateful to people from GENA, the wardens of the Organismo Autónomo de Parques Nacionales (O. A. P. N.), and Javier Zapata, for their help and support. Permits were provided by Conselleria de Medi Ambient del Govern Balear and by Organismo Autónomo de Parques Nacionales. M. G. Forero and J. González-Solís were funded by a Ramón y Cajal grant (Ministerio de Ciencia y Tecnología). This project was partially funded by Ministerio de Ciencia y Tecnología (ref. BOS2003-01960, REN2002-00450).

\section{LITERATURE CITED}

Ainley, D. G., And R. Boekelheide. 1990. Seabirds of the Farallon Islands: ecology, structure and dynamics of an upwelling-system community. Standford University Press, Stanford, CA.

Arroyo, B. E. 2002. Fledging sex ratio variation and future reproduction probability in Montagu's Harrier, Cyrcus pygargus. Behavioral Ecology and Sociobiology 52:109-116.

Astheimer, L. B., And C. R. Grau. 1990. A comparison of yolk growth rates in seabird eggs. Ibis 132: 380-394.

Boersma, P. D., N. T. Wheelwright, M. K. Nerini, And E. S. Wheelwright. 1980. The breeding bi- 
ology of the Fork-tailed Storm-Petrel (Oceanodroma furcata). Auk 97:268-282.

Boersma, P. D., AND J. K. PArrish. 1998. Food delivery to nestling Storm-petrels: limitation or regulation? Functional Ecology 9:161-170.

Bretagnolle, V., And J.-C. Thibault. 1995. Method for sexing fledglings in Cory's Shearwaters and comments on sex-ratio variation. Auk 112:785790.

CALOw, P. 1979. The cost of reproduction-a physiological approach. Biological Review. 54:23-40.

Charnov, E. L. 1982. The theory of sex allocation. Princeton University Press, Princeton, NJ.

Clutton-Brock, T. H. 1986. Sex ratio variation in birds. Ibis 128:317-329.

Cockburn, A., S. Legge, And M. C. Double. 2002. Sex ratios in birds and mammals: can the hypothesis be disentangled?, p. 266-286. In I. C. W. Hardy [ED.], Sex ratios. Concepts and research methods. Cambridge University Press, Cambridge, UK.

Croxall, J. P., P. Rothery, AND A. CrisP. 1992. The effect of maternal age and experience on egg-size and hatching success in Wandering Albatrosses Diomedea exulans. Ibis 134:219-228.

Dijkstra, C., S. DAan, AND J. B. BuKER. 1990. Adaptive seasonal variation in the sex-ratio of Kestrel broods. Functional Ecology 4:143-147.

Ellegren, H. 1996. First gene on the avian W chromosome (CHD) provides a tag for universal sexing of non-ratite birds. Proceedings of the Royal Society of London Series B 263:1635-1641.

Ellegren, H., L. Gustafsson, and B. C. Sheldon. 1996. Sex ratio adjustment in relation to parental attractiveness in a wild bird population. Proceedings of the National Academy of Sciences 93: 11723-11728

EMLEN, S. T. 1997. When mothers prefer daughters over sons. Trends Ecology and Evolution 12:291292.

FISHER, R. A. 1930. The genetical theory of natural selection. Clarendon Press, Oxford.

Fridolfsson, A.-K., AND H. Ellegren. 1999. A simple and universal method for molecular sexing of nonratite birds. Journal of Avian Biology 30:116-121.

Genovart, M. 2001. Seguiment de la colònia de cria de virot Calonectris diomedea a l'illot des Pantaleu. Anuari Ornitològic de les Balears 16:23-27.

Genovart, M., D. Oro, X. Ruiz, R. Griffiths, P. MoNAGHAN, AND R. G. NAGER. 2003. Seasonal changes in brood sex composition in Audouin's gulls. Condor 105:783-790.

Granadeiro, J. P. 1991. The breeding biology of Cory's Shearwater on Berlenga Island, Portugal. Seabird 13:30-39.

Granadeiro, J. P., M. Nunes, M. C. Silva, and R. W. FURNESS. 1998. Flexible foraging strategy of Cory's Shearwater, Calonectris diomedea, during the chick-rearing period. Animal Behaviour 56: 1169-1176.

Griffiths, R., M. C. Double, K. OrR, and R. J. G. DAWSON. 1998. A DNA test to sex most birds. Molecular Ecology 7:1071-1076.

Hamer, K. C., AND J. K. Hill. 1994. The regulation of food delivery to nestling Corys Shearwater $\mathrm{Ca}$ - lonectris diomedea: the roles of parents and offspring. Journal of Avian Biology 25:198-204.

HARris, M. P. 1966. Breeding biology of the Manx Shearwater Puffinus puffinus. Ibis 108:17-33.

HochachKa, W., AND J. N. M. Smith. 1991. Determinants and consequences of nestling condition in song sparrows. Journal of Animal Ecology 60: 995-1008.

HoYT, D. F. 1997. Practical methods of estimating volume and fresh weight of birds eggs. Auk 96:7377.

Hunter, S. 1984. Breeding biology and population dynamics of Giant Petrels Macronectes at SouthGeorgia South Atlantic (Aves Procellariiformes). Journal of Zoology 203:441-460.

IguAL, J. M., AND T. GómEZ. 2000. Seguimiento de la productividad de la Pardela Cenicienta (Calonectris diomedea) en las Islas Chafarinas, p. 124-151. In T. Gómez [ED.]), Control y seguimiento de los ecosistemas en el refugio nacional de caza de las Islas Chafarinas. Organismo Autónomo de Parques Nacionales, Madrid, Spain.

Komdeur, J., S. DaAn, J. Tinbergen, and C. MateMANS. 1997. Extreme adaptive modification in sex ratio of the Seychelles warbler's eggs. Nature 385: 522-525.

Korpimäki, E., C. A. May, D. Parkin, J. Wetton, And J. WIEHN. 2000. Environmental- and parental condition-related variation in sex ratio of kestrel broods. Journal of Avian Biology 31:128-134.

Magrath, R. D. 1991. Nestling weight and juvenile survival in the Blackbird, Turdus merula. Journal of Animal Ecology 60:335-351.

Meathrel, C. E., AND J. P. Ryder. 1987. Sex ratios of Ring-billed Gulls in relation to egg size, egg sequence and female body condition. Colonial Waterbirds 10:72-77.

Mínguez, E. 1998. The costs of incubation in the British Storm-Petrel: an experimental study in a single-egg layer. Journal of Avian Biology 29:183189.

Mougin, J.-L. 1998. Factors affecting egg dimensions and breeding in the Corys Shearwater (Calonectris diomedea) of Selvagem Grande. Journal für Ornithologie 139:179-184.

Mougin, J.-L., C. Jouanin, F. Roux, And F. Zino. 2000. Fledging weight and juvenile survival of Corys Shearwater Calonectris diomedea on Selvagem Grande. Ringing and Migration 20:107-110.

Nager, R., P. Monaghan, R. Griffiths, D. C. HousTON, AND R. DAwson. 1999. Experimental demonstration that offspring sex ratio varies with maternal condition. Proceedings of the Royal Society of London Series B 96:570-573.

Nager, R., P. Monaghan, D. C. Houston, and M. Genovart. 2000. Parental condition, brood sex ratio and differential young survival: an experimental study in gulls (Larus fuscus). Behavioral Ecology and Sociobiology 48:452-457.

Olsen, P., And A. Cockburn. 1991. Female-biased sex allocation in Peregrine Falcons and other raptors. Behavioral Ecology and Sociobiology 28:417423. 
RicklefS, R. E. 1992. The roles of parent and chick in determining feeding rates of Leach's Storm-Petrel. Animal Behaviour 43:895-906.

Ricklefs, R. E., C. DAy, C. Huntington, And J. WilLIAMS. 1985. Variability in feeding rate and meal size of Leach's Storm-Petrel, Thalassoica Antarctica. Behavioral Ecology and Sociobiology 33: $147-150$.

SÁnchez, A., AND A. CAstilla. 1997. La pardela cenicienta (Calonectris diomedea) en las islas Columbretes. Biología y Conservación. Ajuntament de Castelló de la Plana, Castelló de la Plana, Spain.

SCHrEIBER, E. A., AND R. W. SCHREIBER. 1989. Insights into seabird ecology from a global "natural experiment". National Geographic Research Report 5:64-79.

Sibly, R. M., And P. CALow. 1989. A life-cycle theory of responses to stress. Biological Journal of the Linnean Society 37:101-116.

Szczys, P., I. C. T. Nisbet, J. J. HAtch, AND R. V. Kesseli. 2001. Sex ratio bias at hatching and fledging in the roseate tern. The Condor 103:385388.

Thibault, J.-C., V. Bretagnolle, and C. Rabouam. 1997. Calonectris diomedea Cory's Shearwater. BWP Update 1:75-98.

Torres, R., AND H. Drummond. 1997. Female-biased mortality in nestlings of a bird with size dimorphism. Journal of Animal Ecology 66:859-865.
Torres, R., AND H. DRUMmond. 1999. Variably malebiased sex ratio in a marine bird with females larger than males. Oecologia 118:16-22.

Trivers, R. L., AND D. E. WiLLARD. 1973. Natural Selection of parental ability to vary the sex ratio offspring. Science 179:90-92.

VAN DEN Burg, A. B., J. VAN Diermen, J. D. M. MÜSKEnS, S. VAN RIJNAND, AND R. Zollinger. 2002. Sex ratio comparisons between nestlings and dead embryos of the Sparrowhawk Accipiter nisus. Ibis 144:E39-E44.

Velando, A., J. Graves, and J. E. Ortega-Ruano. 2002. Sex ratio in relation to timing of breeding, and laying sequence in a dimorphic seabird. Ibis 144:9-16.

WeIDINGER, K. 1996. Egg variability and hatching success in the Cape Petrel Daption capense at Nelson Island, South Shetland Islands, Antarctica. Journal of Zoology 239:755-768.

Weimerskirch, H., C. Barbraud, AND P. Lys. 2000. Sex differences in parental investment and chick growth in Wandering Albatrosses: fitness consequences. Ecology 81:309-318.

Whittingham, L. A., And P. O. Dunn. 2000. Offspring sex ratios in tree swallows: females in better condition produce more sons. Molecular Ecology 9: 1123-1129.

ZAR, J. H. 1996. Biostatistical Analysis. 3rd ed. Prentice Hall, Upper Saddle River, NJ.

\title{
INCUBATION BEHAVIORS AND PATTERNS OF NEST ATTENDANCE IN COMMON GOLDENEYES IN INTERIOR ALASKA
}

\author{
Joshua H. Schmidt ${ }^{1,4}$, ERIC J. TAYlor ${ }^{2}$ AND ERIC A. ReXSTAD ${ }^{3}$ \\ ${ }^{1}$ Department of Biology and Wildlife, University of Alaska Fairbanks, Fairbanks, AK 99775 \\ ${ }^{2}$ U.S. Fish and Wildlife Service, National Wildlife Refuge System Alaska, 1011 East Tudor Road, \\ Anchorage, AK 99503 \\ ${ }^{3}$ Institute of Arctic Biology, University of Alaska Fairbanks, Fairbanks, AK 99775
}

\begin{abstract}
We hypothesized that nest attendance characteristics in Common Goldeneyes (Bucephala clangula) at the northern limit of their range differ from those of more southern populations. In 2002 and 2003, we used artificial eggs containing temperaturesensing data loggers to obtain nest attendance data from 20 incubating females over 515 days. On average $( \pm \mathrm{SE})$, each female spent $79.8 \pm 0.3 \%$ of the day on the nest, and took $2.9 \pm 0.1$ recesses per day, each
\end{abstract}

Manuscript received 27 June 2004; accepted 18 November 2004.

${ }^{4}$ E-mail: ftjhs2@uaf.edu averaging $100.7 \pm 1.5$ minutes. These recess characteristics were comparable to those reported for other Common Goldeneye populations. Most recesses (88\%) occurred between 09:00 and 22:00 Alaskan Daylight Time although recesses were initiated at all times of day. Female incubation behavior does not appear to be strongly influenced by coarse-level environmental variables or the female-specific variables that we measured, but could be related to a complex assortment of fine-scale environmental or endogenous factors.

Key words: Alaska, Bucephala clangula, Common Goldeneye, incubation, nest attendance, nesting behavior. 